\title{
Correlation of C-Peptide and HbA1c in Type II Diabetes Mellitus
}

\author{
V. Aruna \\ Assistant Professor, Biochemistry, Guntur Medical College, Guntur, Andhra Pradesh, INDIA
}

\begin{abstract}
Type 2 Diabetes Mellitus (Non Insulin Dependent Diabetes Mellitus-NIDDM) is a chronic metabolic disorder most prevalent in India with microvascular complications. Several studies were underway to identify biomarkers to detect complications associated with increasing duration of disease. The present study was done to understand the role of connecting peptide $(\mathrm{C}$ peptide) in pathogenesis of microvascular changes and it's correlation to dyslipidemia of T2DM. The study was done at Government General Hospital, Guntur. In this study 61 known T2 DM patients and 51 age sex matched controls were selected. Their fasting blood samples were analysed for FBS, HbA1C, Urea, Creatinine, Total Cholesterol, High Density Lipoprotein Cholesterol and C-peptide. Dyslipidemia was not observed in Diabetic patients compared to controls (TC, HDLC \& NonHDL $\mathrm{p}=0.363,0.294 \quad \& \quad 0.336$ respectively). $\mathrm{HbA} 1 \mathrm{C}$ and $\mathrm{C}$-peptide showed significant correlation between cases and controls $(\mathrm{P}=<0.00001)$. C-peptide showed significant correlation with lipid parameters \& lipid ratios in individuals with poor glycemic control identified by HbAlc value of $>9 \%$. (ANOVA $\mathrm{p}=<0.0001$ ) Pearson's correlation showed negative relation of $\mathrm{HbA} 1 \mathrm{c}$ and $\mathrm{C}$ peptide with lipid parameters TC, HDLC \& Non $\operatorname{HDLC}(\mathrm{r}=0.378,0.732,0.313$ and $0.81,0.91 \&$ 0.843 consecutively). C-peptide showed significant variation with Non HDL / HDL ratio \& Non HDL / TC ratio $(\mathrm{p}=<0.002$ \& $<0.00007)$ in diabetic patients with poor glycemic control identified by HbA1c of $>9 \%$. We conclude that C-peptide would be a good marker to assess degree of function of pancreas and predictor of atherogenic complication in longstanding NIDDM.
\end{abstract}

Key words: Type 2 Diabetes Mellitus, Cpeptide, HbA1c, Atherogenesis

\section{INTRODUCTION}

Type 2 Diabetes Mellitus (T2DM) is a chronic metabolic disorder characterised by hyperglycemia, dyslipidemia due to deficiency or inappropriate functioning of Insulin, hypoglycemic hormone secreted by $\beta$-cells of pancreas. Its incidence is increasing in the last few years in India with growth rate of $12.5 \%$. The prevalence of type $2 \mathrm{DM}$ is $2.4 \%$ in rural population and $11.6 \%$ in urban population. ${ }^{[1]}$

Insulin resistance with relative Insulin deficiency is feature of T2DM. Proinsulin splits into Insulin and C-peptide (Connecting peptide) before it is released from endocytes of $\beta$ - cells of pancreas. Cpeptide can be estimated in the place of Fasting Insulin to measure endogenous secretion of insulin. C-peptide is com 31 amino acid polypeptide. $50 \%$ of insulin secreted into the portal vein is extracted in liver, hence fasting insulin assay reveals posthepatic concentrations rather than endogenous secretion. ${ }^{[2]} \mathrm{C}$-peptide is not altered in liver \& its assay determines endogenous insulin secretion accurately and discriminates injected insulin. In health normal serum C-peptide level is $0.78-1.89$ $\mathrm{ng} / \mathrm{ml}$. C- peptide binds to receptor at the cell surface, activates G-protein coupled receptor and increases intracellular calcium. C-peptide improves glomerular filtration, increases production of nitric oxide (NO)3 and regulates proinflammatory markers like interleukin 6, tumor nuclear factor $\alpha(\mathrm{TNF} \alpha)$ .C-peptide .C-peptide stimulates migration 
of $\mathrm{T}$ lymphocytes, macrophages and monocytes towards endothelium of capillaries. Increases smooth muscle cell proliferation in the small and medium sized arteries. Proatherogenic affects of C-peptide were studied by Marx et al; ${ }^{[4]}$ Forst et al ${ }^{[5]}$

$\mathrm{Hb}$ undergoes nonenzymatic glycosylation in persons with persistant hyperglycemia and designated as $\mathrm{HbAlc}$. $\mathrm{HbA1c}$ represents the integrated values of glucose over the preceeding 6-8 weeks and provides an additional criterion for assessing glucose control. In health it is $4 \%$ $-7 \%$.

In view of the different complications associated with T2DM several studies were underway to notify specific biomarkers in order to predict forthcoming issues like microangiopathy, metabolic syndrome and hypertension. The etiological factors leading to onset of T2DM include lifestyle, stress, obesity, environmental factors and heredity.

Dyslipidemia is feature of T2DM. Total cholesterol (TC) \&other lipoprotein fractions were analysed routinely to predict coronary heart disease; commonly encountered complication of T2DM. In this study lipid ratios were considered as risk predictors rather than the true values of lipoproteins. Difference between TC and HDLC (High Density Lipoprotein Cholesterol) was considered as Non-HDL fraction of lipids. ${ }^{[6]}$ Non HDL measures all apoB containing lipoproteins and correlates with circulating apoB levels. Considered a better marker for atherogenesis in individuals being treated with lipid lowering drugs like statins. ${ }^{[7]}$ The ratios assessed in this study were cardiac risk ratio $(\mathrm{CRR}=$ TC/HDLC); Atherogenic coefficient ( $\mathrm{AC}=$ Non HDL / HDL) and a novel marker ratio of Non HDL /TC.

Inclusion criteria: Known Type 2 Diabetic patients without complications in the age group of 20 - 60yrs both males and females

Exclusion criteria: Endocrine diseases, Pregnancy, Heart disease

\section{MATERIAL METHODS}

The study was done at GGH, Guntur from January 2020 to March 2020. T2DM patients 61 attending OPD for treatment and 51 age and sex matched healthy individuals as controls were selected for the study after oral informed consent. They were asked to withhold diabetic medication for $48 \mathrm{hrs}$ and attend central biochemistry lab in overnight fasting for sample collection.

Venous blood samples were collected under aseptic conditions. $2 \mathrm{ml}$ mixed with EDTA for estimation of HbA1c and $3 \mathrm{ml}$ collected in red vacutainers. Red vacutainers were centrifuged at $3000 \mathrm{rpm}$ for 5 minutes \& serum was seperated for anaysis of FBS, Total Cholesterol(TC)l, High Density Lipoprotein(HDLC), Urea and Creatinine on Beckman Coultier AU 480.

HbA1c was done by Ion Exchange resin method to assess the glycemic status of the subjects 6 weeks preceding the study.

C-Peptide was evaluated on Access 2 Beckman coultier by immuno radiometric assay (sandwich type). Normal range was $0.78-1.89 \mathrm{ng} / \mathrm{ml}$.

From TC and HDL the following lipid ratios were calculated

1. Cardiac Risk Ratio $(\mathrm{CRR})=\mathrm{TC} \div \mathrm{HDLC}$

2. Non HDL $=$ TC - HDLC

3. Atherogenic coefficient $(\mathrm{AC})=(\mathrm{TC}-$ HDLC) $\div$ HDLC

4. Non HDLC $\div$ TC

Inclusion criteria:- Known cases of Type 2 Diabetes mellitus on oral hypoglycemic agents.

Exclusion criteria:- Endocrine diseases like thyroid disease, Coronary heart disease, Gestational diabetes and microvascular diseases associated with diabetes.

\section{Statistical analysis}

The biochemical values were analysed by NCSS 2021, v21.02 Continuous variables were expressed as mean \pm standard deviation (SD). Analysis of Variance (ANOVA) was done to determine statistical difference between more than two variables. Pearson's correlation was done to investigate correlation between the 
variables. Linear regression model analyses were done to determine trends of mean $\mathrm{C}$ peptide, CRR, AC \& NonHDL/TC ratio. $\mathrm{P}$ value of 0.05 was considered statistically significant.

\section{RESULTS}

Total numbers of 112 subjects were considered for the study - 61 known cases of Type 2DM and 51healthy age and sex matched controls. Among 61 diabetic individuals 31 were females and 30 were males in the age group of 20 - 60yrs.In the controls group 24 were men and 27 were women. Among 61 diabetics longevity of disease was - <5yrs 28 numbers (46\%); > $5 \mathrm{yrs}-18$ numbers $(29 \%)$ and $>10 \mathrm{yrs}-14$ numbers $(23 \%)$.

Table 1 shows Mean \& SD of Biochemical parameters and Lipid ratios in Diabetic subjects and controls. FBS, HbA1c and C-peptide were elevated in Diabetic subjects compared to controls but TC, HDLC were lowered in controls and lipid ratios showed marginal difference between the cases and controls. Diabetic subjects were divided into 2 groups based on HbA1c values- as Poor glycemic control (HbA1c $>9.0 \% \mathrm{~N}=31$ ) and Good glycemic control (HbA1c 4\% $\quad-7 \% \quad \mathrm{~N}=30$ ) Table 2 shows Mean \& SD of Biochemical values and ratios in the 2 groups respectively. Cpeptide levels were higher with better glycemic control. The mean values of FBS, TC, HDL and lipid ratios showed little difference. HbA1c , C-peptide, Non HDL and Non HDL /TC ratio showed statistically significant ( $\mathrm{p}$ values <0.00001, <0.00001, $<0.03$ and $<0.008$ respectively )Table 3 shows 11 individuals with good glycemic control(HbA1c 4\% -7\%) have C-peptide levels of $<0.9 \mathrm{ng} / \mathrm{ml}$ but individuals $(20 \%)$ with poor glycemic control(HbA1c $8.3 \%$ ) have c-peptide levels $>2.0 \mathrm{ng} / \mathrm{ml}$. Increasing fasting sugar values showed higher Cpeptide levels in Diabetic individuals. Amongst diabetics $48 \%$ individuals have HbA1c levels of more than $9 \%$ indicating poor glycemic control. In the same group $\mathrm{HbA1c}$ and C-peptide were significantly correlated with lipid ratios - cardiac risk ratio $\quad(\mathrm{CRR}=\mathrm{TC} / \mathrm{HDLC})$; Atherogenic Coefficient $(\mathrm{AC}=\mathrm{TC}-\mathrm{HDLC} / \mathrm{HDLC})$ and ratio of Non HDLC /TC with $p$ values $<0.00001$ Table 4. Table 2 shows correlation of biochemical values and lipid ratios in poor glycemic control to good glycemic control. HbA1c, C-peptide Non HDL, AC and nonHDL /TC ratio were statistically significant ( $\mathrm{p}$ value $<0.00001$, $<0.00001, \quad<0.03, \quad<0.05$ and $<0.008$ respectively).

Table 1

\begin{tabular}{|l|l|l|l|l|}
\hline & \multirow{2}{*}{ Normal values } & Diabetics(N=61) & Controls(N=51) & P-value \\
\cline { 3 - 5 } & & Mean \pm SD & Mean \pm SD & \\
\hline FBameter & $70-110 \mathrm{mg} / \mathrm{dl}$ & $165.37 \pm 50.4$ & $86.86 \pm 9.78$ & $<0.00001$ \\
\hline HbA1c & $4 \%-7 \%$ & $7.48 \pm 2.74$ & $5.26 \pm 1.63$ & $<0.00001$ \\
\hline C-Peptide & $0.78-1.89 \mathrm{ng} / \mathrm{ml}$ & $2.98 \pm 1.66$ & $4.96 \pm 1.57$ & $<0.00001$ \\
\hline TC & $150-200 \mathrm{mg} / \mathrm{dl}$ & $192.02 \pm 43.29$ & $194.9 \pm 41.82$ & 0.363 \\
\hline HDLC & $35-60 \mathrm{mg} / \mathrm{dl}$ & $45.81 \pm 9.43$ & $44.76 \pm 10.49$ & 0.294 \\
\hline Non HDL & & $146.56 \pm 42.63$ & $150.14 \pm 44.26$ & 0.336 \\
\hline CRR & $<4.5$ & $4.31 \pm 1.49$ & $5.14 \pm 4.41$ & 0.090 \\
\hline AC & $<3.0$ & $3.32 \pm 1.199$ & $3.57 \pm 1.599$ & 0.176 \\
\hline Non HDL $\div$ TC & & $0.75 \pm 0.068$ & $0.75 \pm 0.078$ & 0.416 \\
\hline
\end{tabular}

Table 2: BIOCHEMICAL VALUES IN DIABETIC SUBJECTS WITH POOR GLYCEMIC CONTROL \& GOOD GLYCEMIC CONTROL

\begin{tabular}{|l|l|l|l|}
\hline & Poor glycemic control(N=31) & Good glycemic controls(N=30) & P-value \\
\hline Parameter & Mean \pm SD & Mean \pm SD & \\
\hline FBS & $167.74 \pm 55.37$ & $152.33 \pm 48.94$ & 0.127 \\
\hline HbA1c & $9.55 \pm 1.81$ & $4.991 \pm .29$ & $<0.00001$ \\
\hline C-Peptide & $2.12 \pm 1.40$ & $3.77 \pm 1.14$ & $<0.00001$ \\
\hline TC & $197.81 \pm 45.25$ & $182.2 \pm 38.71$ & 0.07 \\
\hline HDLC & $43.23 \pm 6.64$ & $47.0 \pm 11.16$ & 0.056 \\
\hline Non HDL & $154.9 \pm 43.3$ & $135.53 \pm 38.20$ & $<0.03$ \\
\hline CRR & $4.45 \pm 1.23$ & $4.01 \pm 1.23$ & 0.084 \\
\hline AC & $3.58 \pm 1.06$ & $3.09 \pm 1.24$ & $<0.05$ \\
\hline Non HDL/TC ratio & $0.78 \pm 0.06$ & $0.74 \pm 0.07$ & $<0.008$ \\
\hline
\end{tabular}


Table 3: C-PEPTIDE levels in Diabetic subjects ( $N=$ Number of subjects $=61$ )

\begin{tabular}{|l|l|l|l|}
\hline $\mathbf{N g} / \mathbf{m l}$ & $\mathbf{N}$ & FBS & HbA1c \\
\hline $0-0.9$ & 11 & $169.66 \pm 27.32$ & $6.88 \pm 2.96$ \\
\hline $1-2$ & 41 & $156.48 \pm 37.55$ & $7.42 \pm 2.57$ \\
\hline$>2$ & 09 & $199.55 \pm 92.81$ & $8.3 \pm 3.33$ \\
\hline
\end{tabular}

One way analysis of variance (ANOVA) of mean\& SD of lipid ratios (AC $\&$ NonHDL/TCratio) with C-peptide were significant ( $\mathrm{p}$ values $\quad<0.002 \&<0.00007$ respectively) in poor glycemic control compared to good glycemic control and
HbA1c did not show any significant correlation with lipid ratios. Table 5. The same was not supported by other studies. ${ }^{[9]}$ Diabetes Complications and Control Trial (DCCT) pointed out the influence glycemic status on dyslipidemia and $\mathrm{HbA} 1 \mathrm{c}$ levels of $<7 \%$ prevent microvascular complications. [10]. HbA1c correlated with FBS significantly $(\mathrm{r}=0.459, \mathrm{p}=<0.009)$ in individuals with poor glyemic control.

Table 4: STUDENT'S t TEST IN DIABETICS WITH POOR GLYCEMIC CONTROL

\begin{tabular}{|l|l|l|l|}
\hline PARAMETER & T VALUE & P VALUE & SIGNIFICANCE \\
\hline HbA1C - CRR & 12.968 & $<0.00001$ & SIGNIFICANT \\
\hline HbA1C - AC & 15.858 & $<0.00001$ & SIGNIFICANT \\
\hline HbA1C - NH/TC RATIO & 26.973 & $<0.00001$ & SIGNIFICANT \\
\hline HbA1C -CP & 18.064 & $<0.00001$ & SIGNIFICANT \\
\hline CP- CRR & 6.957 & $<0.00001$ & SIGNIFICANT \\
\hline CP - AC & 4.621 & $<0.0001$ & SIGNIFICANT \\
\hline CP - NH/TC RATIO & 5.326 & $<0.00001$ & SIGNIFICANT \\
\hline
\end{tabular}

Table 5: One-Way Analysis of Variance IN DIABETICS WITH POOR GLYCEMIC CONTROI
\begin{tabular}{|l|l|l|l|}
\hline PARAMETER & F RATIO & P VALUE & SIGNIFICANCE \\
\hline CRR WITH C-PEPTIDE & 1.061 & 0.448 & NS \\
\hline AC WITH C-PEPTIDE & 4.138 & 0.002 & Significant \\
\hline NONHDL / TC RATIO WITH C-PEPTIDE & 6.603 & 0.00007 & Significant \\
\hline CRR WITH HbA1C & 0.213 & 0.995 & NS \\
\hline AC WITH HbA1C & 0.064 & 0.999 & NS \\
\hline NON HDL /TC RATIO WITH HbA1C & 0.060 & 0.999 & NS \\
\hline C-peptide with HbA1C & 134.76 & $<0.00001$ & Significant \\
\hline
\end{tabular}

Pearson's correlation showed Multiple risk assessment systems like marked negative relation between TC, Prospective Cardiovascular Munster study HDLC and Non HDLC fractions of lipids with $\mathrm{HbA} 1 \mathrm{c}$ ( $\mathrm{p}$ values $0.378,0.732 \& 0.313$ respectively) and with $\mathrm{C}$-peptide ( $\mathrm{p}$ values $0 . .81,0.91 \& 0.843$ respectively) Table 6 . Evaluation of Non-HDL as an independent, (PROCAM) ${ }^{[11]}$, Systemic Coronary Risk Estimation (SCORE) include lipid related markers to predict Coronary Artery Disease. But in this study the same could not be established. novel coronary risk factor was under study.

Table 6: PEARSON'S CORRELATION COEFFIENT POOR GLYCEMIC CONTROL(N=31)

\begin{tabular}{|l|l|l|l|}
\hline Correlation with HbA1c & $\mathbf{R}$ & $\mathbf{P}$ & SIGNIFICANCE \\
\hline FBS & 0.4597 & 0.009 & SIGNIFICANT \\
\hline TC & 0.164 & 0.378 & NS \\
\hline HDL & -0.064 & 0.732 & NS \\
\hline NON HDL & 0.187 & 0.313 & NS \\
\hline Correlation with C-Peptide & -0.539 & $<0.001$ & SIGNIFICANT \\
\hline HbA1C & -0.047 & 0.81 & NS \\
\hline TC & -0.0206 & 0.91 & NS \\
\hline HDL & -0.037 & 0.843 & NS \\
\hline NON HDL & \multicolumn{1}{|l}{} \\
\hline
\end{tabular}

LINEAR REGRESSION SCATTER PLOT

X-Axis - C-Peptide; Y-Axis = CRR (1) ; AC (2) \& NonHDL / TC RATIO (3) 


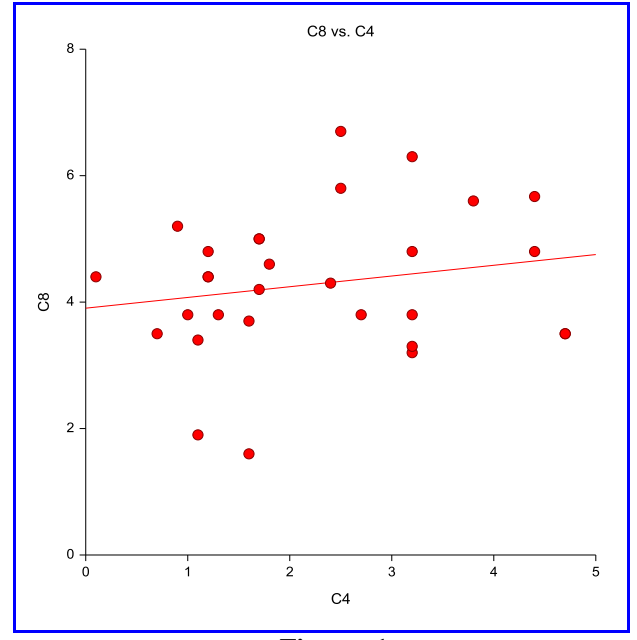

Figure -1

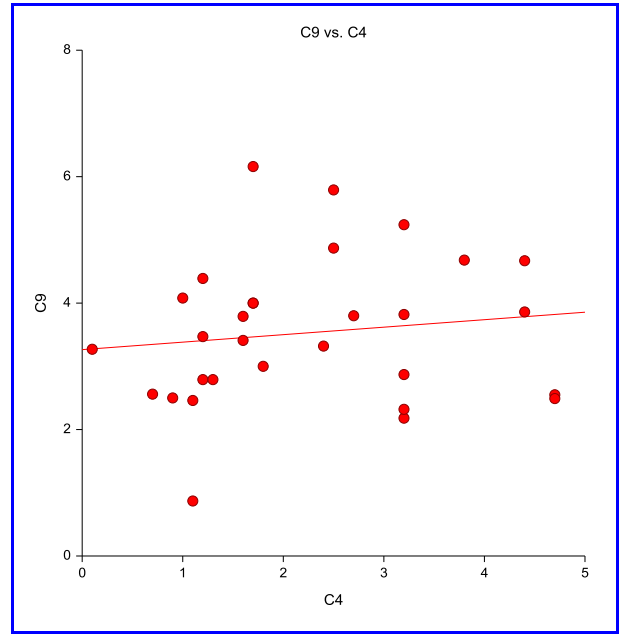

Figure - 2

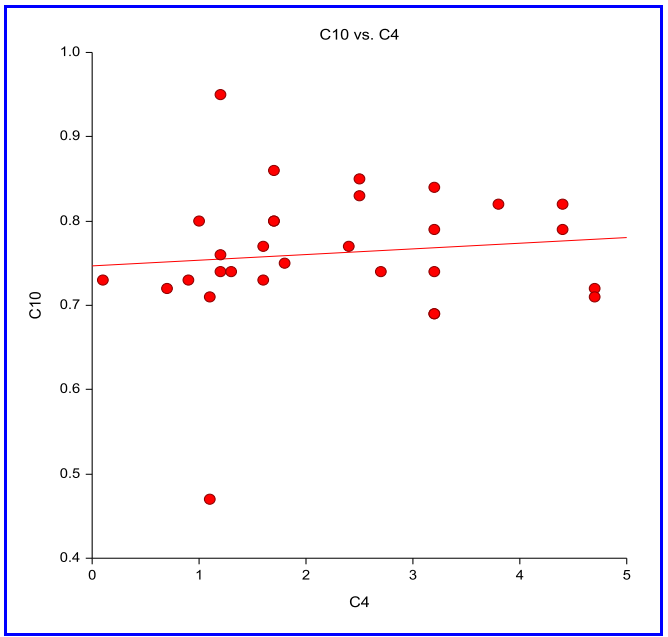

Figure-3

Table 7: LINEAR REGRESSION REPORT IN DIABETIC SUBJECTS (N=61)

\begin{tabular}{|l|l|l|l|l|}
\hline VARIABLE & REGRESSION COEFFICIENT & Std. ERROR & t & P \\
\hline CRR - CP & 4.64 & 0.128 & 36.125 & $<0.00001$ \\
\hline AC - CP & 3.713 & 0.101 & 36.778 & $<0.00001$ \\
\hline TC-HDL/TC -CP & 0.746 & 0.0304 & 24.555 & $<0.00001$ \\
\hline LINEAR REGRESSION IN DIABETICS WITH GOOD GLYCEMIC CONTROL $(\mathrm{N}=30)$ \\
\hline CP -CRR & 5.217 & 0.769 & 6.782 & $<0.00001$ \\
\hline CP - AC & 4.206 & 0.7799 & 5.394 & $<0.00001$ \\
\hline CP - TC-HDL / TC & 0.799 & 0.0424 & 18.845 & $<0.00001$ \\
\hline LINEAR REGRESSION IN DIABETICS WITH POOR GLYCEMIC CONTROL $(\mathrm{N}=31)$ \\
\hline CP - CRR & 3.9105 & 0.427 & 9.154 & $<0.00001$ \\
\hline CP -AC & 3,262 & 0.437 & 7.459 & $<0.00001$ \\
\hline CP - TC-HDL/TC & 0.746 & 0.0304 & 24.55 & $<0.00001$ \\
\hline
\end{tabular}

Table 7 shows Linear regression model for C-peptide with lipid ratios viz CRR, AC \& NONHDL/TC ratio in Diabetic subjects $(\mathrm{N}=61)$, Diabetics with good Glycemic control (HbA1c 4.99\% \pm 1.29 $\mathrm{N}=30$ ) and Diabetics with poor glycemic control (HbA1c $9.55 \% \pm 1.81 ; \mathrm{N}=31)$.Cpeptide was shown to be associated with lipid ratios irrespective of Glycemic status and the adjusted difference was statistically significant with $\mathrm{p}$ value of $<0.00001$.

\section{DISCUSSION}

The present study included Type 2DM patients in the age group of 20-60yrs with equal number of males and females. The concentration of C-peptide was shown to be $50 \%$ in Diabetic subjects $(2.98 \pm 1.66)$ compared to controls $(4.96 \pm 1.57)$. 
The present study proved C-peptide levels were within normal range (0.78 $1.89 \mathrm{ng} / \mathrm{ml}$ ) in Type 2DM individuals irrespective of duration of disease. $50 \%$ individuals were known diabetics for $>5 \mathrm{yrs}$ $\& 25 \%$ for $>10 y$ rs. Glycemic status denoted by $\mathrm{HbA} 1 \mathrm{C}$ levels correlated well with $\mathrm{C}$ peptide $(\mathrm{P}<0.001$ Table 6). C-peptide was associated with lipid ratios as shown in linear regression model of cases with different HbA1c levels. Linear regression analysis demonstrated a strong correlation of c-peptide with lipid ratios $(\mathrm{p}<0.00001)$

Lipid fractions and corresponding lipid ratios were on higher range in controls compared to Diabetic subjects (Table 1). Dyslipidemia of Type 2DM was not observed in this study. TC, HDLC \& NonHDL showed negative correlation with HbA1c (Table 6) in spite of the value being $>9.0 \%(\mathrm{r}=0.164,0.064 \& 0.187 ; \mathrm{p}=0.378$, $0.732 \& 0.313$ consecutively).

Increasing HbA1c levels showed corresponding raise in $\mathrm{C}$-peptide levels (Table 3). Negligible individuals have Cpeptide below the low normal values ie. $<0.9 \mathrm{ng} / \mathrm{ml}$. Significant correlation observed between c-peptide and $\mathrm{HbA} 1 \mathrm{c}$ if the mean exceeded $9 \% \mathrm{p}$ value $<0.001$. The same is true with atherogenic coefficient and nonHDL /Tc ratio by ANOVA $\mathrm{p}$ value $<0.002 \&<0.00007$ consecutively. ${ }^{[12]} \mathrm{We}$ observed poor association of Non HDL levels among controls and diabetics in this study ( $p$ 0.336) where as strong association was demonstrated by Weiquan Lu, et al. ${ }^{[13]}$

In accordance with Linear regression analyses the lipid ratios, indicators of coronary atherosclerosis showed strong association with C-peptide in Type 2Diabetic patients irrespective of their HbA1c levels $(p<0.00001)$ This finding strongly favours assessment of C-peptide in all Type 2 Diabetic patients irrespective of their glycemic status to predict cardiovascular risk. Finally we could not detect any gender difference with the gravity of the situation.

\section{CONCLUSION}

Peptide is a good tool at base level to predict risk of development of Type 2 Diabetes as well as coronary Heart Disease.

\section{ACKNOWLEDGEMENTS}

My sincere thanks to Prof. \& HOD Dr. K. Vijayakumari for her support and encouragement. My heartfelt thanks to central lab staff for their cooperation during workup. My thanks to individuals who cooperated by following instructions to participate in the study.

$\begin{array}{ll}\text { Abbreviations } & \\ \text { Type 2 Diabetes Mellitus } & \text {-T2 DM } \\ \text { Connecting peptide } & \text { - C-Peptide } \\ \text { Total cholesterol } & \text { - TC } \\ \text { High Density Lipoproteins } & \text { - HDLC } \\ \text { Cardiogenic Risk Ratio } & \text { - CRR } \\ \text { Atherogenic Coefficient } & \text { - AC }\end{array}$

Conflict of Interest: None

\section{Source of Funding: None}

\section{Ethical Approval: Approved}

\section{REFERENCES}

1. Anjana R.M., Deepa M., Pradeepa R., Mahanta J., Narain K., Das H.K., Adhikari P., Rao P.V., Saboo B., Kumar A., et al. Prevalence of diabetes and prediabetes in 15 states of India: Results from the ICMRINDIAB population-based cross-sectional study. Lancet Diabetes Endocrinol. 2017;5:585-596. doi: 10.1016/S22138587(17)30174-2. [PubMed]

2. Ferranini E, Cobelli C. The kinetics of insulin in man. Role of the liver. Diabetes Metab Rev 1987; 3:36597.https://doi.org/10.1002/dmr.5610030201

3. Yosten GLC, Maric-Bilkan C, Luppi P, Wahren J. Physiological effects and therapeutic potential of proinsulin Cpeptide. Am J Physiol Endocrinol Metab. 2014;307:E955-E968. doi: 10.1152/ajpendo.00130.2014. [PMC free article] [PubMed] [CrossRef] [Google Scholar]

4. Marx N, Walcher D, Raichle C, et al. Cpeptide colocalizes with macrophages in 
early arteriosclerotic lesions of diabetic subjects and induces monocyte chemotaxis in vitro. Arterioscler Thromb Vasc Biol 2004; 24: 540-545.Google Scholar CrossrefPubMed

5. Forst, T., Kunt, T., Pfützner, A., Beyer, J., Wahren, J., 1998. New aspects on biological activity of C-peptide in IDDM patients. Exp. Clin. Endocrinol. Diabetes 106, 270 276 DOI: $10.1055 / \mathrm{s}-0029-1212190$

6. Anan Huang, Xin Qi, Liping Wei, Mingyin Zhang, Shiqi Zhou, "Non-HDL-c/TC: A Novel Lipid-Related Marker in the Assessment of Severity of Coronary Artery Lesions and Cardiovascular Outcomes", Cardiology Research and Practice, vol. 2019,

7. R. Verbeek, G. K. Hovingh, and S. M. Boekholdt, "Non-high-density lipoprotein cholesterol," Current Opinion in Lipidology, vol. 26, no. 6, pp. 502-510, 2015.View at: Publisher Site | Google Scholar

8. H. E. van Deventer, W. G. Miller, G. L. Myers et al., "Non-HDL cholesterol shows improved accuracy for cardiovascular risk score classification compared to direct or calculated LDL cholesterol in a dyslipidemic population," Clinical Chemistry, vol. 57, no. 3, pp. 490-501, 2011.View at: Publisher Site | Google Scholar

9. Indumati.V, Patil VS, Krishnaswamy, Kumar S, Vijay V, Mahesh S, Rajeshwari V. NON-HDL choleaterol and LDLC/HDL-C Ratio In Type II Diabetic patients. International Journal of Pharma and Bio Sciences. 2011;2:71-7.

10. Gotto AM Jr. Cardiologist's role in improving glucose control and global cardiovascular risk in patients with type 2 diabetes mellitus. Am J Cardiol. 2007:99:35.

11. Buyken AE, von Eckardstein A, Schulte H, Cullen P, Assmann G Type 2 diabetes mellitus and risk of coronary heart disease: results of the 10-year follow-up of the PROCAM study.Eur J Cardiovasc Prev Rehabil. $2007 \quad$ Apr;14(2):2306DOI: 10.1097/HJR.0b013e3280142037

12. Nimmanapalli HD, Kasi AD, Devapatla PK, Nuttakki V. Lipid ratios, atherogenic coefficient and atherogenic index of plasma as parameters in assessing cardiovascular risk in type 2 diabetes mellitus. Int $\mathbf{J}$ Res Med Sci 2016;4: 2863-9.

13. Weiquan Lu, MD, Helaine E. Resnick, PHD, Kathleen A. Jablonski, PHD, Kristina L. Jones, MPH, Arvind K. Jain, MS, Wm. James Howard, MD, David C. Robbins, MD and Barbara V. Howard, PHDNonHDL Cholesterol as a Predictor of Cardiovascular care in Type 2 Diabetes, Diabetic Care 2003 Jan; 26(1): 16-23 .https://doi.org/10.2337/diacare.26.1.16

How to cite this article: V. Aruna. Correlation of c-peptide and hbalc in type ii diabetes mellitus. International Journal of Research and Review. 2021; 8(6): 297-303. DOI: https://doi.org/10. 52403/ijrr.20210637 